\title{
Precipitation trends in Spanish hydrological divisions, 1946-2005
}

\author{
José Carlos Gonzalez-Hidalgo ${ }^{1,2, *}$, Michele Brunetti ${ }^{1}$, Martin de Luis ${ }^{2}$ \\ ${ }^{1}$ ISAC-CNR, Via Gobetti 1001, Bologna, Italy \\ ${ }^{2}$ Department of Geography, University of Zaragoza, Plaza San Francisco sn. 50009, Zaragoza, Spain
}

\begin{abstract}
This paper presents an analysis of precipitation changes in the main Hydrological Divisions (HDs; 'Cuencas Hidrográficas', Water Planning Divisions) in Spain from 1946-2005. Trend analysis revealed several monthly long-term variations and important spatial differences that should be taken into account for any national water-planning scheme. The most spatially coherent signals were a negative trend observed in March and June, affecting all catchments (HDs), and a positive trend in October, which was particularly evident in the northwestern catchments. These caused a redistribution of precipitation throughout the year, with a reduction in the length of the wet season (due to the negative trend in March) and a concentration of precipitation at the beginning of the wet season in October. A running trend analysis revealed variability in the long-term tendency which, although quite persistent, changed in strength between sub-periods.
\end{abstract}

KEY WORDS: Precipitation trend · Running trend · Hydrological Divisions · Water Planning · Spain

Resale or republication not permitted without written consent of the publisher

\section{INTRODUCTION}

One of the most noticeable consequences of global atmospheric warming is water cycle modification (Allen \& Ingram 2002, Huntington 2006), with precipitation being a key point in these processes (Mariotti et al. 2002, Mauget 2006). As a consequence, research into the occurrence and distribution of precipitation has increased over the past few decades, as these are interesting not only from the climatic point of view, but also in terms of water resource management and planning issues. However, precipitation is a difficult research task because of its high spatial variability, both in terms of absolute values and in trend signal; in fact, no generalised pattern in precipitation trends has been found either on a global scale (New et al. 2001, Giorgi 2002), regional scale (Klein-Tank et al. 2002, Xoplaki et al. 2004, Norrant \& Douguédroit 2006) or sub-regional scale (Brunetti et al. 2006b, Gonzalez-Hidalgo et al. 2010). Moreover, the effects of precipitation trends on water cycles in future scenarios remain uncertain, with local peculiarities prevailing over a generalised tendency.

Climate transition areas are the most interesting territory for such analyses, and the region around the
Mediterranean Sea in particular is one of the best examples (Lavorel et al. 1998, Lionello \& Giorgi 2007). In the Mediterranean area, precipitation presents large spatial gradients. As in other semiarid regions, it can be said that water is the most important natural resource from a social and ecological point of view in the Mediterranean basin, and thus precipitation is a climate variable of high interest.

This premise has been recognised by the Spanish National Climate Report when stating that 'precipitation is the most important climate element in Spain' (de Castro et al. 2005, p. 9). Precipitation variability has caused severe problems over the last few decades in Spain, generating a social and political debate that did not achieve a general consensus for establishing an accepted basis for water planning and future management of the most essential natural resources (Barreira 2003, Pulido-Calvo et al. 2003, Embid \& Gurrea 2004). At the beginning of the 1990s, a long, persistent drought period caused high stress to agricultural and forest areas (Peñuelas et al. 2001, Vicente 2006, GarcíaHerrera et al. 2007, Vicente-Serrano \& Cuadrat-Prats 2007), while at the end of the 1990s and beginning of the 2000s, heavy rainfall caused floods with human 
and financial losses (Llasat et al. 2003, Barrera et al. 2007, Barnolas et al. 2008).

This also explains why so much research has been conducted on this topic for the last decade in Spain. The analyses have sometimes been performed on a national scale in an attempt to identify a general pattern covering the whole area (Rodríguez Puebla et al. 1998, Gonzalez Rouco et al. 2001, Mosmann et al. 2004, Sotillo et al. 2006, Valero et al. 2009, Gonzalez-Hidalgo et al. 2010). The general conclusion is that no generalised, significant trends in precipitation have been detected. On the other hand, a great deal of other research has been carried on sub-regional and local scales (e.g. Romero et al. 1998, Ceballos et al. 2004, Saladié et al. 2004, del Río et al. 2005, Caramelo \& Manso-Orgaz 2007, Ramos-Calzado et al. 2008), which results are difficult to compare as station densities and the period under examination vary greatly (see the recent review by Gonzalez-Hidalgo et al. 2010).

The most appropriate spatial scale for assessing the effect of climate change on water resources should be the catchments, as these are the natural hydro-climatic units. However, only a few studies have focused on this scale in the conterminous regions of Spain (i.e. on catchment analysis): data are available for the Duero basin (Caramelo \& Manso-Orgaz 2007), the Ebro basin (de Luis et al. 2008), the Tagus basin (Lopez-Moreno et al. 2009) and the Guadiana basin (Conan et al. 2003). These studies demonstrated that although isolated Hydrological Divisions (HDs) are commonly used for hydro-climatic analyses in Spain, no country-wide picture has been produced using the main 'Cuencas Hidrográficas', i.e. HDs.

In the present study, we analysed the precipitation trends in Spanish HDs for the last 60 yr (1946-2005) using a regional series referring to the main HDs. The analysis was performed from the densest database of monthly precipitation ever produced in Spain for the 1946-2005 period, converted to HD series for comparison. The objectives of the paper were to detect changes in trends during the study period and characterise the trend of precipitation on a water-planning scale (HD).

\section{STUDY AREA AND METHODS}

\subsection{Study area}

High temporal and spatial variability characterise the Spanish precipitation regime due to complex orography, latitudinal position and location between 2 contrasting water masses (Atlantic Ocean and Mediterranean Sea). Pre- cipitation during the wet period (October-March) is usually related to baroclinic synoptic scale perturbations moving eastward from the Atlantic Ocean, while convective and more local processes are characteristic of summer (del Río et al. 2005 and references therein). Mean annual precipitation values range from $>1500 \mathrm{~mm}$ in the northwest to $<250 \mathrm{~mm}$ in the southeast, and variability increases from west to east.

Spain is divided into 10 major HDs for water-planning administration. Fig. 1 shows the spatial distribution of HDs, and Table 1 lists their main characteristics. Note that some parts of the Duero (HD 2), Tagus (HD 3), and Guadiana HD (HD 4) are located in Portugal, and our data only covered the area within conterminous Spain.

Precipitation distribution throughout the year differs from HD to HD. In Table 2, the mean monthly percentage contribution (1946-2005) to annual precipitation is presented for each HD. Northern and western HDs (1 to 6) have a winter maximum (Dec-Jan-Feb), and autumn (Sep-Oct-Nov) is the second most important season in terms of percentage contribution, while the eastern HDs $(7$ to 9,0$)$ located along the Mediterranean fringe, exhibit 2 maxima in autumn and spring.

As noted above, the spatial distribution of precipitation in Spain shows a well-documented northwest to southeast pattern from a northwest maximum to southeast minimum (de Castro et al. 2005). If we compare this to the spatial distribution of the population, economic activities and agricultural needs, a clear imbalance can be detected in the main water planning of HDs, because the principal water storage areas are located in the Pyrenees (HD 9) and headwaters of

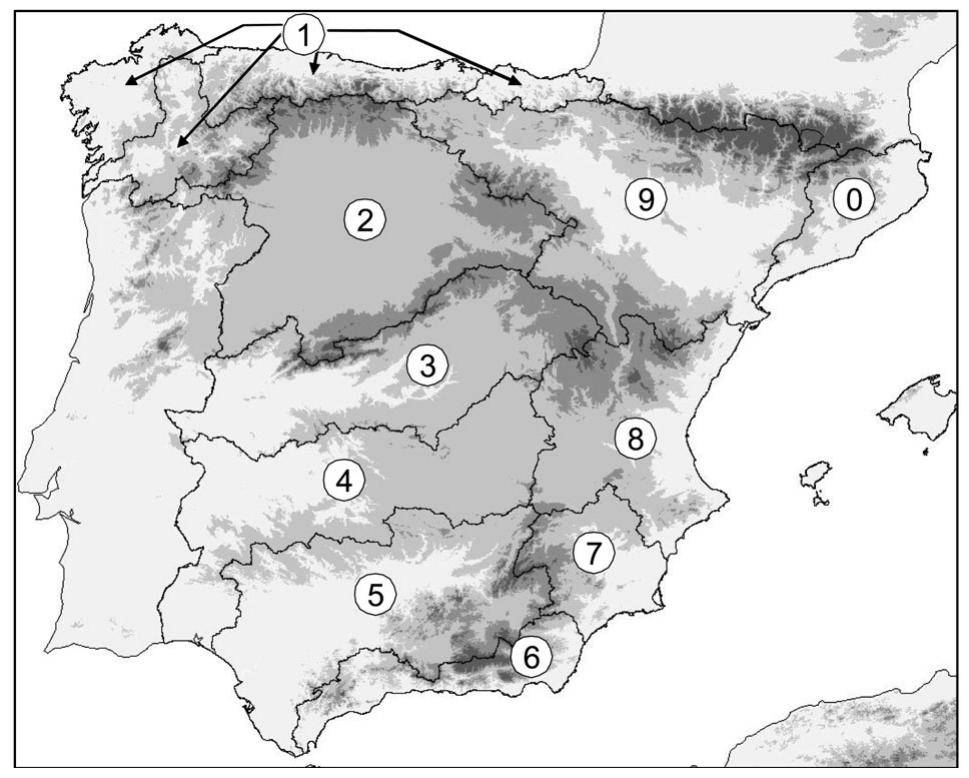

Fig. 1. Hydrological Divisions of Spain. HD 1 is subdivided into 4 subsections that were not analysed in this paper 
Table 1. Main characteristics of Hydrological Divisions (HD) of Spain

\begin{tabular}{|c|c|c|c|c|c|}
\hline HD & Code & $\begin{array}{l}\text { Surface } \\
\left(\mathrm{km}^{2}\right)\end{array}$ & $\begin{array}{r}\text { area } \\
(\%)\end{array}$ & $\begin{array}{c}\text { Population } \\
(\%)\end{array}$ & $\begin{array}{c}\text { Population } \\
\text { density } \\
\text { (ind. } \mathrm{km}^{-2} \text { ) }\end{array}$ \\
\hline Eastern pyrenees & HD0 & 16493 & 3.3 & 16.4 & 426.7 \\
\hline North & HD1 & 53804 & 10.9 & 14.7 & 117.0 \\
\hline Duero & HD2 & 78972 & 16.0 & 6.0 & 32.4 \\
\hline Tagus & HD3 & 54769 & 11.1 & 17.7 & 13.6 \\
\hline Guadiana & HD4 & 59873 & 12.2 & 4.0 & 28.7 \\
\hline Guadalquivir & HD5 & 63085 & 12.8 & 12.7 & 86.6 \\
\hline Eastern Andalusia & HD6 & 18391 & 3.7 & 5.2 & 121.3 \\
\hline Segura & $\mathrm{HD} 7$ & 18254 & 3.7 & 3.3 & 78.1 \\
\hline Júcar & HD8 & 42904 & 8.7 & 13.1 & 131.5 \\
\hline \multirow[t]{2}{*}{ Ebro } & HD9 & 86098 & 17.5 & 7.0 & 34.9 \\
\hline & & $\begin{array}{c}\text { Total } \\
492643\end{array}$ & & $\begin{array}{l}\text { Total (no.) } \\
42960173\end{array}$ & $\begin{array}{c}\text { Mean } \\
87.2\end{array}$ \\
\hline
\end{tabular}

HDs 2 to 4, while the highest consumption (mostly for irrigation) is located in the central lowland plains of HDs 2 to 5 and 9, and on the Mediterranean coast.

Thus, water planning in Spain is rendered difficult, due to the spatial distribution of water resources in relation to population and economic activities. If we leave aside some inland cities (particularly Madrid in HD 3, Valladolid in HD 2 and Zaragoza in HD 9), the spatial distribution of the population in Spain is mainly concentrated in the Mediterranean and northern coastlands. The HDs along the Mediterranean coast (HDs $0,8,7,6$ ) represent only $19.4 \%$ of total conterminous Spain, whereas people living in this area comprise $37 \%$ of the total population.

A second important feature for water planning in Spain is the distribution of agricultural activities. From the total area dedicated to agriculture, $87 \%$ is used for rain-fed farming and the remaining $13 \%$ is irrigated, generating $55 \%$ of total agricultural production. The total area of irrigated land in Spain in 1999 was about $3 \times 10^{4} \mathrm{~km}^{2}$; this has been increased to approximately $3.12 \times 10^{4} \mathrm{~km}^{2}$ at present, representing $15 \%$ of the

Table 2. Percentage contribution of monthly precipitation in Hydrological Divisions (HD) to the total annual amount estimated over the 1946-2005 period

\begin{tabular}{|ccccccccccccc|}
\hline HD & Jan & Feb & Mar & Apr & May & Jun & Jul & Aug & Sep & Oct & Nov & Dec \\
\hline 1 & 11.8 & 10.0 & 9.2 & 8.5 & 7.7 & 4.8 & 2.9 & 3.8 & 6.2 & 9.9 & 12.1 & 13.1 \\
2 & 10.5 & 8.9 & 8.6 & 8.9 & 10.1 & 6.6 & 3.4 & 3.3 & 6.5 & 10.3 & 11.5 & 11.6 \\
3 & 10.9 & 10.1 & 9.1 & 9.2 & 9.6 & 5.2 & 1.9 & 2.1 & 6.2 & 11.1 & 12.1 & 12.6 \\
4 & 11.5 & 11.0 & 9.8 & 9.9 & 8.6 & 4.6 & 1.1 & 1.5 & 5.2 & 11.0 & 12.1 & 13.6 \\
5 & 12.5 & 11.5 & 10.7 & 9.5 & 7.6 & 3.2 & 0.7 & 1.0 & 4.5 & 10.7 & 12.8 & 15.2 \\
6 & 12.8 & 11.5 & 11.0 & 9.4 & 6.3 & 2.4 & 0.5 & 1.1 & 4.4 & 10.9 & 14.0 & 15.8 \\
7 & 8.0 & 8.4 & 8.8 & 12.1 & 10.3 & 6.3 & 1.9 & 3.3 & 8.3 & 13.1 & 9.7 & 9.9 \\
8 & 7.5 & 7.7 & 7.9 & 9.9 & 10.5 & 7.1 & 3.3 & 4.9 & 8.9 & 12.8 & 9.5 & 9.9 \\
9 & 7.7 & 6.7 & 7.4 & 9.5 & 11.2 & 8.5 & 5.0 & 6.2 & 8.8 & 9.9 & 9.7 & 9.4 \\
0 & 6.2 & 5.8 & 7.4 & 8.4 & 10.7 & 8.4 & 5.2 & 8.7 & 11.0 & 11.8 & 8.3 & 8.0 \\
\hline
\end{tabular}

total conterminous land under cultivation (Table 3). This surface area consumes approximately $80 \%$ of annual water demand, while urban consumption is about $14 \%$ and industry $6 \%$. About $70 \%$ of the water for irrigation comes from surface water resources such as dams and reservoirs. At present, Spain has some 1200 large dams in operation, with a total capacity of over $56 \mathrm{~km}^{3}$.

The 2 largest areas of irrigated lands are located in inland valleys (such as HDs 9, 2 to 5) and in the intensive, irrigated areas on the east-southeast coast in the provinces of Almería, Murcia, Alicante and Valencia, i.e. the coastal provinces of HDs 6 to 8. However, the most important water harvesting systems are located in the Pyrenees (HD 9) and headwaters of the rivers Duero, Tagus, and Guadiana (HDs 2 to 4). Table 3 shows an estimation of land under irrigation in each HD as a percentage of the HD surface and as a percentage of total national irrigated area.

\subsection{Methods}

A correct evaluation of time evolution of water availability at the catchment scale requires knowledge, at each time step, of the precipitation falling on any point on the basin surface and its integration over the whole basin area. This could theoretically be possible only with a very high density of stations available over the area. Unfortunately, this is not possible in practice because the required station density to describe the strong spatial gradients of precipitation regimes correctly is usually orders of magnitude higher than any existing data set covering at least a $50 \mathrm{yr}$ period. This is especially true for mountain areas, where station density is typically lower and precipitation presents stronger spatial gradients. To circumvent this problem, we simply reconstructed relative changes in total precipitation over each catchment (HD), instead of the absolute values over the 1946-2005 period. The MOPREDAS database (Gonzalez-Hidalgo et al. 2010) was used for this purpose.

The MOPREDAS database consists of 2670 complete monthly station series all covering the period 1946-2005 and was developed by a massive analysis of the total amount of monthly precipitation data stored in the archives of the National Meteorological Agency of 
Table 3. Surface irrigated in Hydrological Divisions (HD) of Spain in 2007, showing the total surface area under irrigation (Total irr.), and HD irrigated surface area as a percentage of the HD surface area ( $\%$ of HD) or as a percentage of the total national irrigated surface area (\% of total). Source: Ministerio de Agricultura y Medio Ambiente, Gobierno de España, www. mapa.es/es/ministerio/pags/anuario2007/anuario2007.htm; www.mapa.es/

\begin{tabular}{|cccc|}
\hline HD & Total irr. $\left(\mathrm{km}^{2}\right)$ & \% of HD & \% of total \\
\hline 1 & 253.5 & 0.5 & 0.8 \\
2 & 3966.8 & 5.0 & 12.7 \\
3 & 2034.8 & 3.7 & 6.5 \\
4 & 3552.1 & 5.9 & 11.4 \\
5 & 6914.8 & 11.0 & 22.2 \\
6 & 1006.0 & 5.5 & 3.2 \\
7 & 1700.4 & 9.3 & 5.5 \\
8 & 4602.6 & 10.7 & 14.8 \\
9 & 6189.9 & 7.2 & 19.9 \\
0 & 940.8 & 5.7 & 3.0 \\
& Total & Mean & Total \\
& 31161.6 & 6.3 & 100.0 \\
\hline
\end{tabular}

Spain (AEMET), after an exhaustive quality control including the detection (and discarding) of suspicious data and homogeneity analyses. Details of this procedure can be found in Gonzalez-Hidalgo et al. (2009, 2010).

A $0.1^{\circ}$ resolution grid was constructed by interpolating the station series into a regular grid by means of weighted averages, with weights depending on the distance of the stations from the target grid cell and their angular separation (see Gonzalez-Hidalgo et al. 2010 for a detailed description of the weights).

The grid resolution of $0.1^{\circ}$ is the most suitable to the station density. It is sufficiently high to allow basin areas to be cut out with precision, but not enough to allow a precise evaluation of inflow into each basin due to the strong spatial gradient of total precipitation (the deviation from the mean has good spatial coherence, but absolute values present strong spatial gradients; Mitchell \& Jones 2005).

These reasons led us to estimate the time evolution of the precipitation falling into each catchment area by averaging all grid cells falling into each HD domain, and converting the final HD series into anomalies (multiplicative anomalies) by dividing each monthly value by its climate normal estimated over the 19462005 period.

For each HD, the monthly series, the wet and dry seasons (defined as October-March and April-September series, respectively) and hydrological year series were estimated over the 1945-2005 period.

Trend analysis by ordinary least-squares regression was applied to each series to detect any change in the inflow of each HD. Statistical significance was assessed via the non-parametric Mann-Kendall test.
To highlight whether the trend signal was persistent over the whole time period spanned by the data, a running trend analysis was also applied by estimating trends over time windows of variable width ranging from 20 yr up to the length of the entire series, running from the beginning to the end of the time series. For a detailed discussion of this technique, see Brunetti et al. (2006a) and a similar approach proposed by Matti et al. (2009).

\section{RESULTS}

\subsection{Trend analysis}

On a monthly scale, March and June (negative trend) and October (positive trend) showed the highest levels of significance (Table 4).

During March (Fig. 2), we detected a significant decrease in total precipitation amounts $(p<0.05)$ in all HDs except 7 and 8 . The strongest trends affected the western area of Spain (HD 4), with a rate of decrease of $-18 \%$ decade $^{-1}$ (Table 4 ). The spatial distribution of negative trends in June (data not shown) was similar to March (Table 4), but significance and rates of decrease were lower (ranging between -3 and $-8 \%$ decade $^{-1}$, Table 4). The highest and most significant trends were achieved in northwestern catchments (HDs 1 to $3, \mathrm{p}<$ 0.10 , Table 4), and decreased progressively moving towards eastern and southern areas (HDs 4, 8, 9, 0, p < 0.20; HDs 5 to $7, \mathrm{p}>0.20$ ).

October was the only month showing a positive significant trend (Fig. 3, Table 4). The most significant p-values were found in the northwest (HDs 1 and 2, $\mathrm{p}<0.05)$ followed by HD $3(\mathrm{p}<0.10)$ and HD 4 ( $\mathrm{p}<$ $0.20)$. The precipitation increase ranged from +7 to $+11 \%$ decade $^{-1}$.

If the whole hydrological year is considered, the only trends significant at $p<0.20$ were found for the southeast area of Spain (HDs 6 to 8; Table 4). This suggests that in western HDs, the positive trends observed in October compensated the precipitation decreases registered in other months (March in particular), producing a redistribution of precipitation throughout the year rather than changes in the total amount.

All catchments, except HD 0, showed slightly negative trends in the wet season and were significant for few HDs only. These negative trends were more relevant in the Mediterranean sector (HDs 7 and 8 in particular), due to the strong negative trend of March, not completely compensated by the positive trend of October. No significant trend was observed in the dry season except in HDs 3 and 9.

As a result of the low and rarely significant trend observed in the hydrological year series and the signif- 
Table 4. Hydrological Division (HD) trend analyses. Monthly, wet season (Wet), dry season (Dry) and hydrological year (Hydr) trend (from MOPREDAS database October 1945-September 2006). Trends as percentage of change decade ${ }^{-1}( \pm \mathrm{SD})$. $\mathrm{p}<0.20$, except bold values: $\mathrm{p}<0.05$; italic values: $\mathrm{p}<0.10$; sign $(+/-)$ : $\mathrm{p}>0.20$

\begin{tabular}{|c|c|c|c|c|c|c|c|c|c|c|c|c|c|c|c|}
\hline HD & Jan & Feb & Mar & Apr & May & Jun & Jul & Aug & Sep & Oct & Nov & Dec & Wet & Dry & Hydr \\
\hline 1 & - & - & $-8 \pm 4$ & + & - & $-8 \pm 4$ & $+8 \pm 4$ & - & - & $+7 \pm 4$ & - & - & - & - & - \\
\hline 2 & + & - & $-14 \pm 5$ & + & + & $-7 \pm 4$ & + & + & - & $+11 \pm 5$ & - & + & - & - & - \\
\hline 3 & - & $-11 \pm 6$ & $-17 \pm 5$ & - & - & $-6 \pm 5$ & - & - & - & $+10 \pm 5$ & + & + & - & $-5 \pm 3$ & - \\
\hline 4 & - & $-12 \pm 6$ & $-18 \pm 5$ & - & - & $-4 \pm 6$ & - & - & - & $+8 \pm 5$ & + & + & - & - & - \\
\hline 5 & - & - & $-16 \pm 5$ & - & - & - & $-3 \pm 11$ & - & + & + & + & + & - & - & - \\
\hline 6 & $-3 \pm 6$ & - & $-10 \pm 5$ & $-9 \pm 5$ & - & - & - & - & + & + & + & + & - & - & $-2 \pm 2$ \\
\hline 7 & $-7 \pm 5$ & + & - & $-18 \pm 6$ & - & - & - & - & + & - & + & - & $-4 \pm 2$ & - & $-3 \pm 2$ \\
\hline 8 & - & - & $-8 \pm 5$ & - & - & $-3 \pm 5$ & $-11 \pm 7$ & $-7 \pm 5$ & + & - & + & - & $-2 \pm 2$ & - & $-2 \pm 2$ \\
\hline 9 & - & - & $-8 \pm 4$ & + & - & $-5 \pm 4$ & - & - & - & + & $+4 \pm 4$ & - & - & $-2 \pm 1$ & - \\
\hline 0 & + & - & $-10 \pm 5$ & + & - & $-4 \pm 4$ & - & - & - & + & $+7 \pm 6$ & + & + & - & - \\
\hline
\end{tabular}

icant trends characterising some months, changes in the contribution of monthly precipitation to total annual amount occurred between 1946 and 2006. Table 5 shows the relative changes in monthly percentage contribution to total annual amount (ratios 1976-2005/1946-1975) for each HD. The most noticeable changes occurred in March, July and October, despite the fact that changes in precipitation in July involved a low quantity of precipitation (less than 5.2\% of the annual amount) while March and October changes affected about $20 \%$ of the mean annual amount. Thus, March and October trends produced a redistribution of precipitation within the wet season causing a concentration at the beginning of the season, which consequently became shorter.

\subsection{Running trend analyses}

Trend values shown in Table 4 are relative to the whole period covered by the different catchment series. To evaluate the temporal stability of the trend signal, the HD series were analysed for trends using a running approach (Brunetti et al. 2006a).

The slopes of the trends were estimated within temporal windows of widths ranging from $20 \mathrm{yr}$ up to the length of the entire series. The trends obtained were plotted for better visualisation in graphs where the $y$ axis represents the window width, and the $x$-axis the first year of the window the trend refers to. All values along the same abscissa correspond to sub-series having the same starting year but different length (i.e. different end year); all values along the same ordinate correspond to sub-series having the same length but a different starting and ending year; finally, all values along a line parallel to the hypotenuse correspond to sub-series having the same ending year but a different length (i.e. different starting year). The value of the trend is represented by the colour of the corre- sponding pixel and the significance level by the dimension of the squares: large squares are plotted for $\mathrm{p}<0.05$, medium squares for $\mathrm{p}<0.10$ and small squares for the remainder $(p>0.10)$. These figures capture the whole possible spectrum of significant trends present in the series, thus providing the most highly detailed information. For more details, see Brunetti et al. (2006a).

Given the relevance of March and October trends and their important contribution to total annual precipitation amount (see Table 2), this analysis focused on these 2 months (see Figs. 4 \& 5), along with the wet season (see Fig. 6).

In March (Fig. 4), HDs 3, 4, 5, 6 and 8 (i.e. all southern Spain, except HD 7) presented the strongest negative trend in the sub-series starting from the large maximum located at end of the 1960s (see Fig. 2) and ending with the minimum of the late 1980s/early 1990s, increasing thereafter to the last year.

The same HDs 3 to 6 and 8, along with HDs 2 and 9, showed a wide range of time scales characterised by negative and highly significant trends, the only exceptions being the later decades and the early period already discussed, which were not significant, and in some cases were positive, such as for HDs 8 and 9.

HDs 1 and 0 showed similar behaviour, with almost all trends being negative, but with no change in trend direction over the last few decades (i.e. in these HDs, the negative trend still persisted).

Completely different was the trend behaviour of HD 7. The most interesting features were the positive and significant trends in all sub-series ending around 1975 and the negative trends in sub-series starting in the late 1960s. These features were also partially evident in HD 8, but with a lower level of significance, indicating that in March the eastern catchments (HDs 7 and 8) along the Mediterranean coast behaved differently with respect to the western ones on a wide range of time scales. 

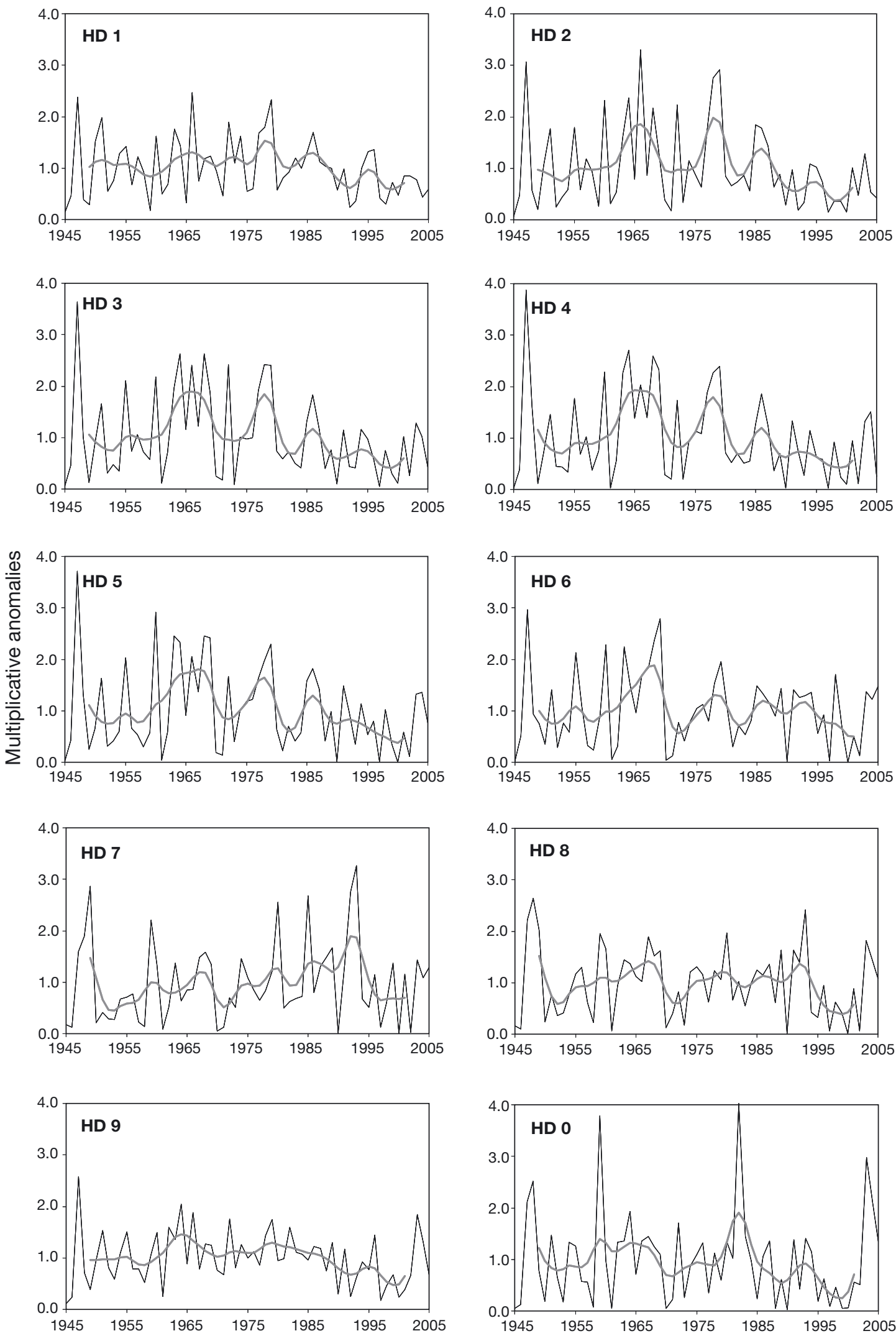

Fig. 2. March precipitation trend by Hydrological Division (HD), 1946-2005 (see Fig. 1 for division locations). Grey line smoothing (low pass filter, lag 9) 

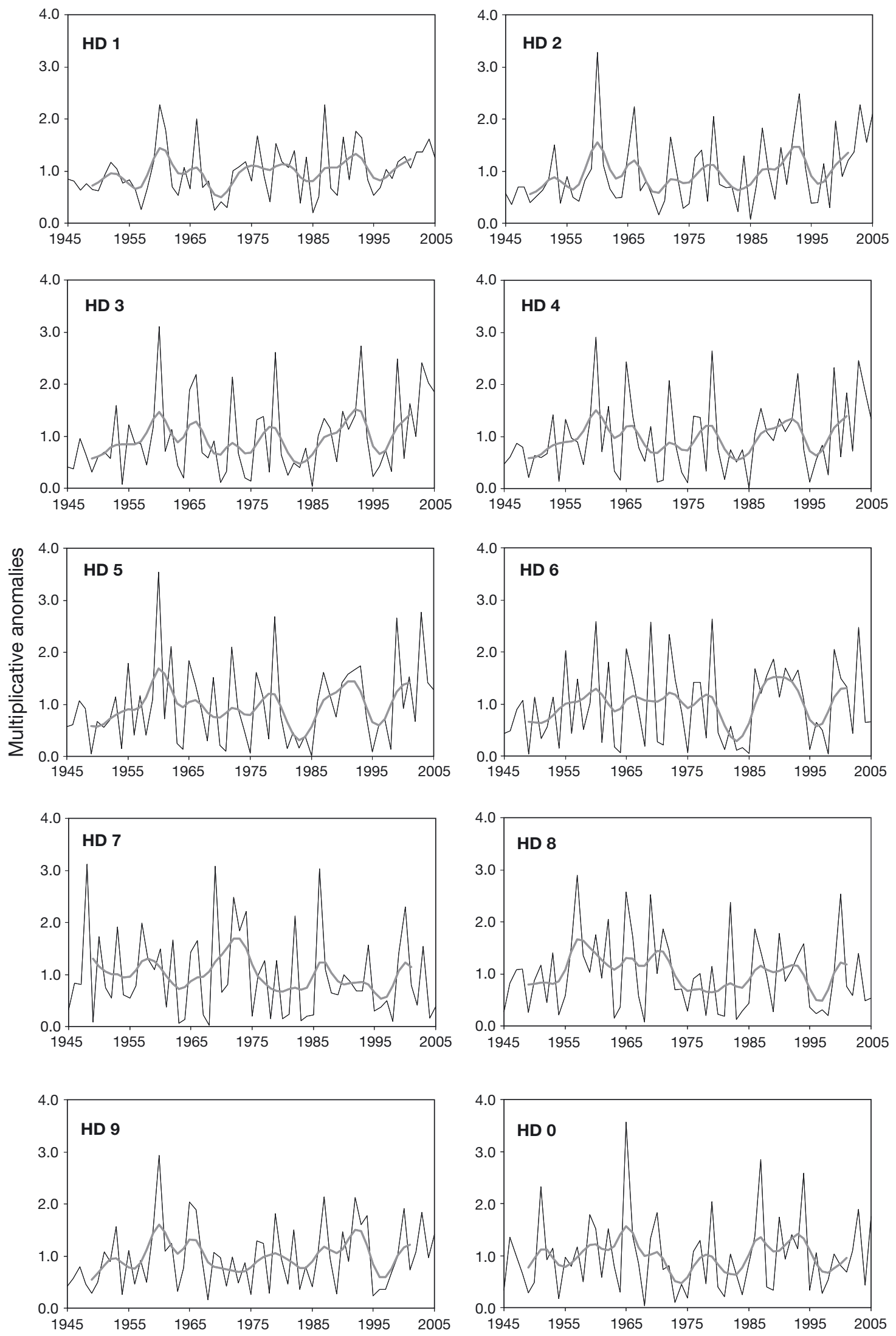

Fig. 3. As in Fig. 2, but for October 
Table 5. Relative monthly precipitation changes expressed as a ratio between 1976-2005 and 1946-1975 by Hydrological Division (HD)

\begin{tabular}{|c|c|c|c|c|c|c|c|c|c|c|c|c|}
\hline HD & Jan & Feb & Mar & Apr & May & Jun & Jul & Aug & Sep & Oct & $\mathrm{Nov}$ & Dec \\
\hline 1 & 0.92 & 0.91 & 0.79 & 1.22 & 1.00 & 0.83 & 1.50 & 1.01 & 0.92 & 1.30 & 0.95 & 1.06 \\
\hline 2 & 0.90 & 0.84 & 0.61 & 1.20 & 1.04 & 0.80 & 1.18 & 1.31 & 0.93 & 1.39 & 0.95 & 1.25 \\
\hline 3 & 0.91 & 0.79 & 0.58 & 1.09 & 1.03 & 0.82 & 1.23 & 1.19 & 0.88 & 1.41 & 1.10 & 1.29 \\
\hline 4 & 0.91 & 0.78 & 0.53 & 1.10 & 1.00 & 0.84 & 1.41 & 1.07 & 1.08 & 1.33 & 1.21 & 1.26 \\
\hline 5 & 0.92 & 0.82 & 0.58 & 1.06 & 0.98 & 0.86 & 1.41 & 1.05 & 1.11 & 1.30 & 1.25 & 1.19 \\
\hline 6 & 1.02 & 0.97 & 0.66 & 0.87 & 0.93 & 0.87 & 1.39 & 0.90 & 1.15 & 1.18 & 1.22 & 1.09 \\
\hline 7 & 1.07 & 1.40 & 0.85 & 0.73 & 1.23 & 0.88 & 1.39 & 1.00 & 1.18 & 0.81 & 1.26 & 0.91 \\
\hline 8 & 1.18 & 0.99 & 0.68 & 1.07 & 1.15 & 0.92 & 0.92 & 0.88 & 1.08 & 0.85 & 1.27 & 1.03 \\
\hline 9 & 1.07 & 0.91 & 0.73 & 1.21 & 1.06 & 0.87 & 1.05 & 1.01 & 0.84 & 1.24 & 1.04 & 0.98 \\
\hline 0 & 1.55 & 0.96 & 0.70 & 1.06 & 1.04 & 0.90 & 1.02 & 0.95 & 0.85 & 1.08 & 1.26 & 0.94 \\
\hline
\end{tabular}

In October (Fig. 5), HDs 1 to 4 and partially 5 and 9 (i.e. in northeastern Spain) presented some interesting significant trend patterns: all sub-series ending recently and those ending in the early 1990s presented significant positive trends, due to the relative maxima in October precipitation at the end of the series and around 1990 (see Fig. 3). Similarly, HDs 5, 6 and partly 3,8 and 0 , showed significant negative trends for all sub-series ending in the mid-1980s, where 1 of the strongest minima of the series was located (see Fig. 3). In addition to these features, HD 8 also showed significant negative trends in the sub-series starting around the mid-1950s, where the maximum of the series was located (Fig. 3). The same is true for catchment 0, but with positive trends for the sub-series starting at the beginning of $1970 \mathrm{~s}$, which was a clear minimum.

The wet season (Fig. 6) showed some features differentiating western catchments (mainly HDs 3, 4 and 5 in the southwest, and partially 1 and 2 in the northwest) from eastern, more Mediterranean, ones (HDs 7 and 8). In particular, western catchments (HDs 3, 4 and 5, and partially 1 and 2) presented a clear, highly significant negative trend in all sub-series starting around 1960, where the most prominent maximum in the time series was observed, and an increase in the first decades. On the Mediterranean side, in HDs 8 and 7 in particular, the majority of sub-series ending in the last few years and those ending around 1985 presented negative trends, significant in HD 8 but not always in HD 7. On the contrary, all sub-series ending around 1990 and those ending at the end of the 1950s presented positive trends, mostly significant in HD 7 but rarely in HD 8 . These features were mainly linked to the minima located around 1980 and in the late 1990s (for negative trends) and to the maxima located at the end of the 1950s and around 1990 (for positive trends). HD 6 showed a behavioural trend that represented a type of transition between those of the east and west.

HDs 9 and 0 presented a 3-phase trend, with a positive trend in the first decades and a decrease in the second part of the series concluding again with a positive trend in the later decades (although not significant). These trends were often significant in HD 9, but rarely in HD 0.

\section{DISCUSSION AND CONCLUSIONS}

The analysis of precipitation series from the Water Planning Divisions (HDs) of conterminous Spain highlighted precipitation trends over the period 1946-2005 with very low significance levels, either for the total annual amount, or for the wet and dry seasons. However, significant and spatially coherent trends were identified on a monthly scale, particularly in March (mainly negative) and October (mainly positive), but also in June, characterised by mainly negative trends albeit with a weaker statistical significance than those observed in March. Contrary to the spatially coherent trends of March, June and October is the high spatial variability of trends observed in the other months, for which heterogeneous behaviour was observed.

The opposite trends observed for March and October produced a redistribution of precipitation within the wet season (from October to March), causing a concentration of precipitation at the beginning of the season, which became shorter.

Previous research has highlighted the decrease of precipitation in March in the Iberian Peninsula, particularly in western areas (Serrano et al. 1999b, Paredes et al. 2006, Trigo \& DaCamara 2000, del Río et al. 2005, 2010, Gonzalez-Hidalgo et al. 2010). These changes have been linked to a northward shift of the Atlantic storm track, and to the negative trend of westerly and northwesterly cyclones, coupled with a strengthening of the NAO (Paredes et al. 2006). All of these aspects are consistent with the negative trend over the past $40 \mathrm{yr}$ in the frequency of cyclones, detected for March, with a low located in the area extending from the Azores archipelago in the mid-Atlantic Ocean to the 

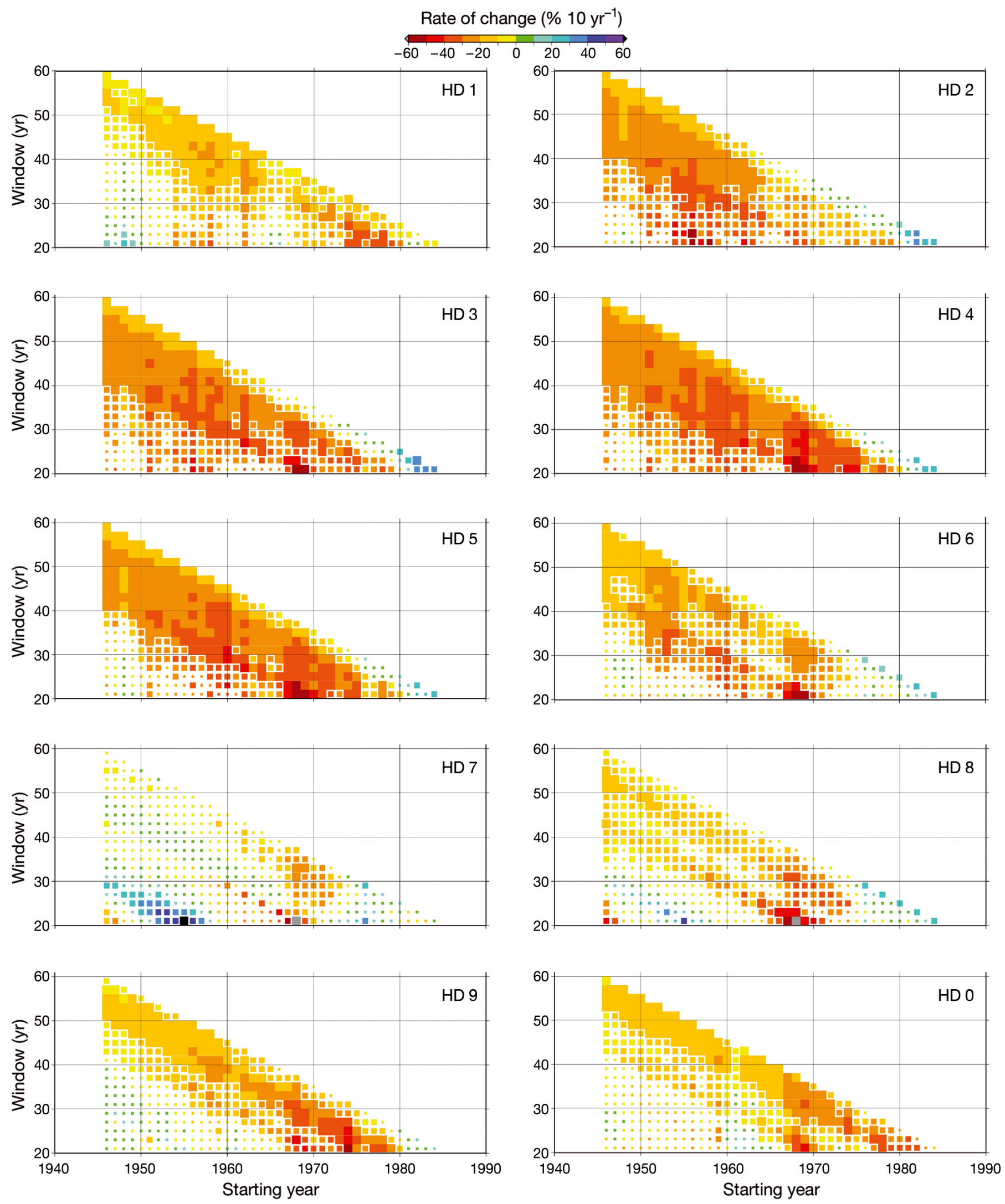

Fig. 4. Running-trend analyses for October by Hydrological Division (HD). The size of squares represents $p$-levels $(p<0.05$, $\mathrm{p}<0.10$ and $\mathrm{p}>0.10)$. Colours represent rate of change $\left(\% 10 \mathrm{yr}^{-1}\right)$. See 'Results' (Section 3.2) for more details 

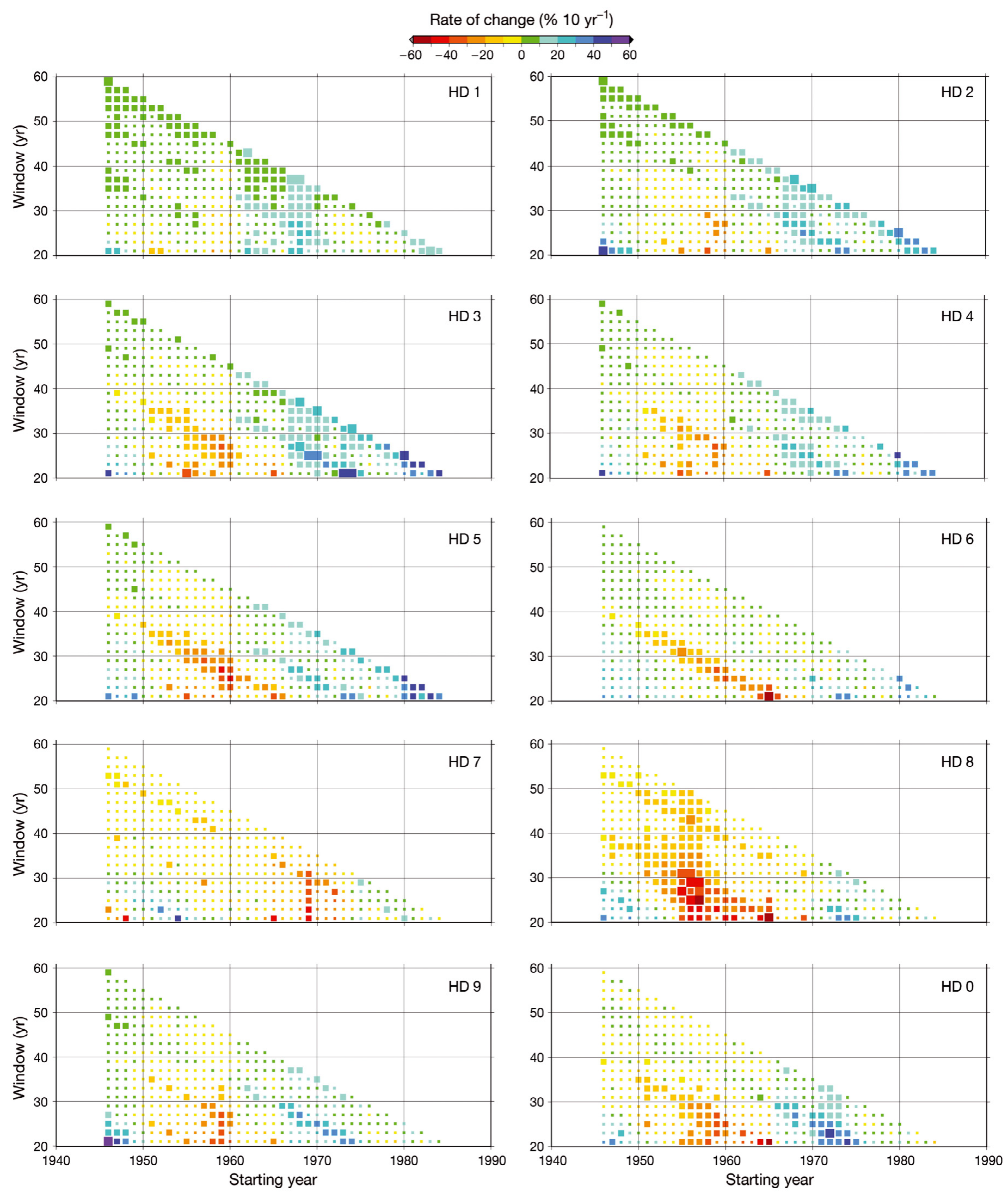

Fig. 5. As in Fig. 4, but for March 

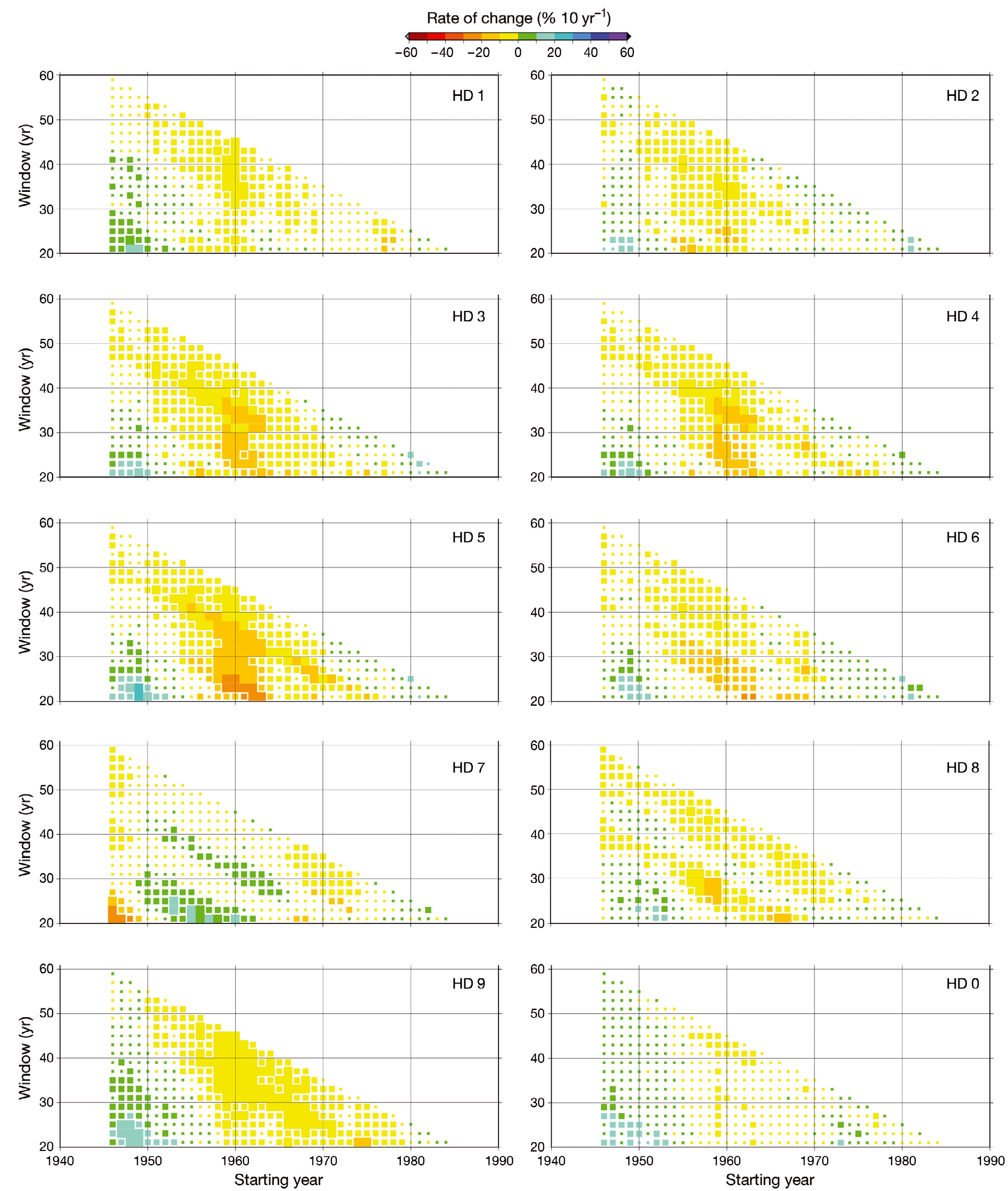

Fig. 6. As in Fig. 4, but for the wet season (from October to March) 
west of Iberia (Paredes et al. 2006). Also, the positive trend in sunshine duration and anticyclonic activity in March observed by Sánchez-Lorenzo et al. (2007) over Spain is consistent with the precipitation decrease. However, these features did not directly affect the Mediterranean fringe of the Iberian Peninsula (HD 7 to 9 and 0 ), where no clear trends were detected. In fact, this area is mainly affected by Mediterranean cyclones, with a low located in the westernmost Mediterranean basin (Jansa et al. 2001), for which no trends in frequency of occurrence have been observed over the last $50 \mathrm{yr}$, neither in spring nor other seasons (Bartholy et al. 2009).

As far as the positive trend of October is concerned, similar results were indicated by Ceballos et al. (2004) and del Río et al. (2010), and were briefly discussed by Paredes et al. (2006). The area with such a positive significant precipitation trend is located in the northwestern part of the region, affected by the 'Galicia and Portugal' pattern, described by Serrano et al. (1999a), which consists of a centre of low pressure located near the British Isles, typically associated with frontal precipitation. In a seasonal analysis of precipitation of the northwestern area of HD 1, Lorenzo et al. (2008) suggested that such a positive trend in precipitation was highly correlated with South-Western and Western weather types (the first being associated with a depression to the west of Ireland with a large anticyclone over the Iberian Peninsula and the rest of Europe, and the second being characterised by depressions over the North Atlantic and the north of Europe, with high pressure over the Azores), both closely linked and positively correlated to the Eastern Atlantic pattern that, during October of the later decades, exhibited a positive trend, yielding more South-Western situations (Lorenzo et al. 2008). More recently, Lorenzo et al. (2010) suggested a possible relationship between precipitation in the northwestern Iberian Peninsula and sea surface temperature of the Atlantic Ocean using different temporal lags. For eastern catchments, affected by Mediterranean cyclones (Jansa et al. 2001), the absence of significant tendencies is consistent with cyclone activity along the whole western Mediterranean coast (in sectors I, II and III, as defined by Bartholy et al. 2009), for which no trends have been observed over the past half century (Bartholy et al. 2009).

The aforementioned precipitation trends are not monotonic, and changes in trend slope and significance were detected in different sub-periods. These aspects were highlighted by a running trend analysis, which also helps in comparing our results to other studies performed over different periods. Particularly interesting is the inversion (from negative to positive) of the trend sign in March precipitation over the last decade, characterising almost all HDs.
Even if past precipitation trends are not indicative of future tendencies, these results are valuable for waterplanning agencies and should be taken into account. Moreover, the high resolution MOPREDAS dataset used here for catchment analysis is an important instrument that enables a statistical downscaling of future scenarios at a suitable spatial resolution, which is necessary for the evaluation of future water availability on a hydrological division scale.

Acknowledgements. We thank the following Contract Grant Sponsors: Gobierno de España, Proyecto CGL2008-05112C02-01/CLI, Gobierno Regional de Aragón DGA, Grupo de Investigación Consolidado 'Clima, Agua, Cambio Global y Sistemas Naturales' (BOA 69, 11-06-2007) and EU-COSTACTION ES0601 'Advances in homogenization methods of climate series: an integrated approach (HOME)'. This paper was written while J.C.G.H. was a visiting researcher at ISACCNR of Bologna (Italy), under Programa de Movilidad de Investigadores - Programa Salvador de Madariaga (Gobierno de España). Original precipitation data were provided by the Agencia Estatal de Meteorología (AEMET, Spanish National Meteorological Agency).

\section{LITERATURE CITED}

Allen MR, Ingram WJ (2002) Constraints on future changes in climate and the hydrological cycle. Nature 419:224-232

Barnolas M, Atencia A, Llasat MC, Rigo R (2008) Characterization of a Mediterranean flash flood event using rain gauges, radar, GIS and lightning data. Adv Geosci 17: $35-41$

- Barreira A (2003) The participatory regime of water governance in the Iberian Peninsula. Water Int 28:350-357

> Barrera A, Altava-Ortiz V, Llasat MC, Barnolas M (2007) Heavy rain prediction using deterministic and probabilistic models - the flash flood cases of 11-13 October 2005 in Catalonia (NE Spain). Adv Geosci 12:121-126

Bartholy J, Pongrácz R, Pattantyús-Ábrahám M (2009) Analyzing the genesis, intensity, and tracks of western Mediterranean cyclones. Theor Appl Climatol 96:133-144

Brunetti M, Nanni T, Maugeri M, Auer I, Böhm R, Schöner W (2006a) Precipitation variability and changes in the Greater Alpine Region over the 1800-2003 period. J Geophys Res 111:D11107 doi:10.1029/2005JD006674

> Brunetti M, Maugeri M, Monti F, Nanni T (2006b) Temperature and precipitation variability in Italy in the last two centuries from homogenised instrumental time series. Int J Climatol 26:345-381

- Caramelo L, Manso-Orgaz MD (2007) A study of precipitation variability in the Duero Basin (Iberian Peninsula). Int $\mathrm{J}$ Climatol 27:327-339

Ceballos A, Martinez J, Luengo MA (2004) Analysis of rainfall trends and dry periods on a pluviometric gradient representative of Mediterranean climate in the Duero Basin, Spain. J Arid Environ 58:215-233

Conan C, de Marsily G, Bouraoui F, Bidoglio G (2003) A longterm hydrological modelling of the Upper Guadiana river basin (Spain). Phys Chem Earth 28:193-200

de Castro M, Martín-Vide J, Alonso S (2005) El clima de España: pasado, presente y escenarios de clima para el siglo XXI. Impactos del cambio climático en España. Ministerio Medio Ambiente, Madrid 
de Luis M, Gonzalez-Hidalgo JC, Longares LA, Stepanek P (2008) Regímenes estacionales de la precipitación en loa vertiente mediterránea de la Península Ibérica. Cambio climático regional y sus impactos. Publ AEC Ser A 6:81-90

del Río S, Peñas A, Fraile R (2005) Analysis of recent climatic variations in Castile and Leon (Spain). Atmos Res 73: 69-85

del Río S, Herrero L, Fraile R, Penas A (2010) Spatial distribution of recent rainfall trends in Spain (1961-2006). Int J Climatol doi:10.1002/joc.2111

Embid A, Gurrea F (2004) Relevance and application of the EU water directive in terms of Spain's National Hydrological Plan. Water Sci Technol 49:111-116

> García-Herrera R, Paredes D, Trigo R, Franco-Trigo I, Hernández E, Barriopedro D, Mendes MD (2007) The outstanding 2004/05 drought in the Iberian Peninsula: associated atmospheric circulation. J Hydrometeorol 8:483-498

Giorgi F (2002) Variability and trends of subcontinental scale surface climate in the twentieth century. I. Observations. Clim Dyn 18:675-691

Gonzalez-Hidalgo JC, López-Bustins JA, Štepánek P, MartínVide J, de Luis M (2009) Monthly precipitation trends on the Mediterranean fringe of the Iberian Peninsula during the second half of the 20th century (1951-2000). Int J Climatol 29:1415-1429

Gonzalez-Hidalgo JC, Brunetti M, de Luis M (2010) A new tool for monthly precipitation analysis in Spain: MOPREDAS database (Monthly precipitation trends December 1945-November 2005). Int J Climatol doi:10.1002/ joc. 2115

González-Rouco JF, Jiménez JL, Quesada V, Valero F (2001) Quality control and homogeneity of precipitation data in the southwest of Europe. Int J Climatol 14:964-978

$>$ Huntington TG (2006) Evidence for intensification of the global water cycle: review and synthesis. J Hydrol (Amst) 319:83-95

> Jansa A, Genoves A, Picornell MA, Campins J, Riosalido R, Carretero O (2001) Western Mediterranean cyclones and heavy rain. Part 2: Statistical approach. Meteorol Appl 8:43-56

Klein-Tank AM, Wijngaard JB, Können GP, Böhm R and others (2002) Daily dataset of 20th-century surface air temperature and precipitation series for the European Climate Assessment. Int J Climatol 22:1441-1453

Lavorel S, Canadell J, Rambal S, Terradas J (1998) Mediterranean terrestrial ecosystems: research priorities on global change effects. Glob Ecol Biogeogr Lett 7:157-166

Lionello P, Giorgi F (2007) Winter precipitation and cyclones in the Mediterranean region: future scenarios in a regional simulation. Adv Geosci 12:153-158

Llasat MC, Rigo T, Barriendos M (2003) The 'Montserrat2000' flash-flood event: a comparison with the floods that have occurred in the northeastern Iberian Peninsula since the 14th century. Int J Climatol 23:453-469

López-Moreno JI, Vicente-Serrano S, Beguería S, García-Ruiz JM, Portela MM, Almeida AB (2009) Dam effects on droughts magnitude and duration in a transboundary basin: the Lower River Tagus, Spain and Portugal. Water Resour Res 45:W02405 doi:10.1029/2008WR007198

Lorenzo MN, Taboada JJ, Gimeno L (2008) Links between circulation weather types and teleconnection patterns and their influence on precipitation patterns on Galicia (NW Spain). Int J Climatol 28:1493-1505

Lorenzo MN, Iglesias I, Taboada JJ, Gómez-Gesteira M (2010) Relationship between monthly rainfall in northwest Iberian Peninsula and North Atlantic sea surface temperature. Int J Climatol 30:980-990
Mariotti A, Struglia MV, Zeng N, Lau KM (2002) The hydrological cycle in the Mediterranean region and implications for the water budget of the Mediterranean Sea. J Clim 15:1674-1690

> Matti C, Pauling A, Küttel M, Wanner H (2009) Winter precipitation trends for two selected European regions over the last 500 years and their possible dynamical background. Theor Appl Climatol 95:9-26

Mauget SA (2006) Intra- to multi- decadal terrestrial precipitation regimes at the end of the 20th century. Clim Change 78:317-340

Mitchell TD, Jones PD (2005) An improved method of constructing a database of monthly climate observations and associated high-resolution grids. Int J Climatol 25:693-712

Mosmann V, Castro A, Fraile R, Dessens J, Sánchez JL (2004) Detection of statistically significant trends in the summer precipitation of mainland Spain. Atmos Res 70:43-53

> New M, Todd M, Hulme M, Jones P (2001) Precipitation measurements and trends in the twentieth century. Int J Climatol 21:1889-1922

Norrant C, Douguédroit A (2006) Monthly and daily precipitation trends in the Mediterranean (1950-2000). Theor Appl Climatol 83:89-106

Paredes D, Trigo RM, Garcia-Herrera R, Franco-Trigo I (2006) Understanding precipitation changes in Iberia in early spring: weather typing and storm-tracking approaches. J Hydrometeorol 7:101-113

Peñuelas J, Lloret F, Montoya R (2001) Severe drought effects on Mediterranean woody flora in Spain. For Sci 47:214-218

> Pulido-Calvo I, Roldán J, López-Luque R, Gutiérrez-Estrada JC (2003) Water delivery system planning considering irrigation simultaneity. J Irrig Drain Eng 129:247-255

Ramos-Calzado P, Gómez-Camacho J, Pérez-Bernal F, PitaLópez MF (2008) A novel approach to precipitation series completion in climatological datasets: application to Andalusia. Int J Climatol 28:1525-1534

Rodríguez-Puebla C, Encinas AH, Nieto S, Garmendia J (1998) Spatial and temporal patterns of annual precipitation variability over the Iberian Peninsula. Int J Climatol 18:299-316

Romero R, Guijarro JA, Alonso S (1998) A 30-year (19641993) daily rainfall data base for the Spanish Mediterranean regions: first exploratory study. Int J Climatol 18: $541-560$

Saladié O, Brunet M, Aguilar E, Sigró J, López D (2004) Variaciones y tendencia secular de la precipitación en el sistema Mediterráneo catalán (1901-2000). El Clima, entre el mar y la montaña. Asociación Española de Climatología, Santander, p 399-408

Sánchez-Lorenzo A, Brunetti M, Calbó J, Martin-Vide J (2007) Recent spatial and temporal variability and trends of sunshine duration over the Iberian Peninsula from a homogenized data set. J Geophys Res 112:D20115 doi: 10.1029/2007/JD008677

Serrano A, Garcia JA, Mateos VL, Cancillo ML, Garrido J (1999a) Monthly modes of variation of precipitation over the Iberian peninsula. J Clim 12:2894-2919

Serrano A, Mateos VL, Garcia JA (1999b) Trend analysis of monthly precipitation over the Iberian Peninsula for the period 1921-1995. Phys Chem Earth B Hydrol Oceans Atmos 24:85-90

Sotillo M, Martín ML, Valero F, Luna MY (2006) Validation of a homogeneous 41-year (1961-2001) winter precipitation hindcasted dataset over the Iberian Peninsula: assessment of the regional improvement of global reanalysis. Clim Dyn 27:627-645

Trigo RM, DaCamara C (2000) Circulation weather types and 
their influence on the precipitation regime in Portugal. Int J Climatol 20:1559-1581

Valero F, Martín ML, Sotillo MG, Morata A, Luna MY (2009) Characterization of the autumn Iberian precipitation from long-term datasets: comparison between observed and hindcasted data. Int J Climatol 29:527-541

Vicente S (2006) Spatial and temporal analysis of droughts in the Iberian Peninsula (1911-2000). Hydrol Sci J 51:83-97

Editorial responsibility: Filippo Giorgi,

Trieste, Italy
Vicente-Serrano SM, Cuadrat-Prats JM (2007) Trends in drought intensity and variability in the middle Ebro valley (NE of the Iberian peninsula) during the second half of the twentieth century. Theor Appl Climatol 88:247-258

Xoplaki E, González-Rouco F, Luterbacher J, Wanner H (2004) Wet season Mediterranean precipitation variability: influence of large scale dynamics and trends. Clim Dyn 23:63-78

Submitted: May 25, 2010; Accepted: September 14, 2010 Proofs received from author(s): October 18, 2010 